\title{
Investigation of Entrepreneurship Levels and Employability Perception of Undergraduate Students Studying Sports Sciences
}

\author{
Mustafa TAZE ${ }^{1} \&$ Metin KARAYOL ${ }^{2}$ \\ ${ }^{1}$ Department of Physical Education and Sports Education, Graduate of Social Sciences, Muş Alparslan University, \\ Muş, Turkey \\ ${ }^{2}$ School of Physical Education and Sports, Muş Alparslan University, Muş, Turkey \\ Correspondence: Metin KARAYOL, School of Physical Education and Sports, Muş Alparslan University, Turkey. \\ E-mail: metin_karayol@hotmail.com
}

Received: January 12, 2020

Accepted: February 20, 2020

Online Published: March 24, 2020

doi:10.5539/ies.v13n5p35

URL: https://doi.org/10.5539/ies.v13n5p35

\begin{abstract}
The aim of this study is to investigate Entrepreneurship levels and Employability perceptions of Undergraduate Students in the department of Sports Sciences. Population of the study consists of the undergraduate students studying Sports Sciences in Eastern Anatolia region. Sample group of the study consists of 597 undergraduate students studying Sports Sciences ay 4th grade in Eastern Anatolia region. The personal information form has been used to identify the demographic features of the participants by the researchers. "Employability Scale" transcribed to Turkish by Karl (2016) has been used to determine the employability of the participants and "Entrepreneurship Scale For Teacher Candidates" developed by Deveci and Çepni (2015) has been used to identify their conditions of entrepreneurship. Besides descriptive statics such as arithmetic average, standard deviation, frequency/percentage, normal distribution test, (Kolmogorov-Smirnov test) to test the hypothesis of the study, t-test (Mann-Withney U test) in pairwise comparison and variance analysis (Kruskal Wallis-H test) in multiple comparisons and correlation test (Spearman Correlation test) have been conducted. After the variance analysis, bonferroni correction method has been used to prevent type I and type II mistakes caused by pairwise comparisons conducted to identify in which groups there is a significant difference. SPSS 23 statistical package program has been used to create the tables and evaluate the data obtained from the study. As a consequence: while there is a significant difference according to variables of Condition of Taking Entrepreneurship Course, and Department in sub-dimensions of Employability Scale and Entrepreneurship Scale For Teacher Candidates, no significant difference has been seen according to Gender. Significant difference and relations have been found out in the entrepreneurship levels and employability.
\end{abstract}

Keywords: sports management, sports sciences, entrepreneurship, employability

\section{Introduction}

In today's world, it is getting harder and harder to survive or live as an individual with welfare level day by day with increasing population. In global world, current situations of continents, regions, countries, cities etc. in economic area can show differentiation. This difference becomes more of an issue in terms of continuing one's life. As individuals are affected by many factors while they continue their lives, both entrepreneurship activities and opportunities of employability which can be happened as a consequence of government, private sector or their own personal efforts are incontrovertible.

Concept of entrepreneurship is derived from the word "entreprende" which means "to do something, to undertake" in French. French economist Richard Cantillon used this concept firstly. Richard Cantillon has used this concept to make profit by undertaking the risks that organize the work (Havinal, 2009). Entrepreneurship according to Hisrich and Peters (2002) is a process of creating a new value involving having economic rewards and personal satisfaction, social, psychological and financial risks and freedom dealed with enough time and effort. Kuratko (2009) on the other hand states that entrepreneurship is a process of creating a living vision and distinctness requiring energy and passion in terms of creative solutions and new ideas performing them in real life. Entrepreneur is the person who becomes prominent with his creativity and produces by finding the product or service that society needs (Kaya, 2007). According to the definition of Turkish Language Association, entrepreneur is defined as an individual who entrepreneurs by capitalizing for production in trade industry areas 
and etc.

First definitions about employment have been stated by Beveridge in 1909 when searching the reasons of unemployment in England (Hillage \& Pollard, 1998). Before 1950s, the concept of "socio-medical employability" concentrating on occupational needs of the disadvantaged people in terms of especially physical, intellectual, and social showed up in America, England and Germany. Since 1960s, especially America has improved "Manpower Policy Employability "policy fronting the employment of socially disadvantaged groups. Although the previous researches were dealing with the concept of employability as more of a macro concept, current studies have been expanding the meaning of the concept in the scope of individual career management components (Arthur \& Rousseau, 1996). Despite of the fact that his concept has been formed by the companies desiring to have multiple labor force, the employability ability of the individual has more of a micro context (Forrier \& Sels, 2003).

Saygll, Cihan, and Yurtoğlu (2002) define the employability as it should be used for production of business and labor force in any country so they state that the development to happen in employability would contribute financial growth.

Kocackk (2000) states that employability shows the number of work in economy. Therefore, according to the author, employability level points out the working level and it is calculated as the rate of the individuals that are employed to total workforce.

Sport is in important position in terms of individuals adapting to the society and sense of belonging (Eroğlu \& Acet, 2017). In this context, when looking up to the conditions of employability and entrepreneurship in physical education and sports of Turkey, we can say that we have reached a structure that becomes professional in status of developing countries. Along with the increase in importance of Physical Education and Sports in Turkey, the increase in course hours of physical education and sports in primary and secondary education, universities' providing students individuals who have sport background convenience in entering the related departments, governments' awarding successful sportsmen and especially in 2011 with 2nd Sports Ministry term's beginning and by defining definitions of many physical education and sports departments in government status.

We can see that special employability areas are provided. In addition to that, coaching courses of both federations and public authorities an opportunity has been provided in increasing of individual entrepreneurship thoughts and employability areas.

From this point, in our study it has been aimed to investigate the employability perceptions and entrepreneurship levels of undergraduate students in the department of Sports Science in Eastern Anatolia Region of Turkey.

\section{Method}

\subsection{Research Model}

Research has been designed in Descriptive and Relational scanning model.

\subsection{Population and Sample}

Population of the study consists of Sports Science students studying at 4th grade in Eastern Anatolia Region. When identifying the sample of research, complete inventory sample method has been used and sample group consists of 230 females,367 males out of 597 students in total who are studying at 4th grade in department of Sports Science (Coaching training, Physical Education for people with disabilities, Sport teaching, Physical Education and Sport Teaching, Recreation education and Sports Management) at universities (Ağrı İbrahim Çeçen U., Ardahan U., Atatürk U., BitlisEren U., Erzincan BinaliYıldırım U., Fırat U., İnönü U., Kafkas U., \& Van YüzüncüYıl U.)

\subsection{Data Collection}

"Entrepreneurship Scale for Teacher Candidates" has been used to identify the entrepreneurship conditions of undergraduate students. "Entrepreneurship Scale" developed by Deveci and Çepni (2015) consists of 5 sub dimensions and 38 questions. Sub dimensions are as below; they involve Questions of Risk Taking (1.2.3.4.5.6.7.), questions of Seeing Opportunities (8.9.10.11.12.13.14.15.16.), Questions of Self Confidence (17.18.19.20.21.22.23.), and finally Questions of Being Innovator (32.33.34.35.36.37.38.). It has been found out that Cronbach's alpha internal consistencies related to sub dimensions of the scale are between .77 and .83.

"Employability Scale" has been used to identify the employment conditions of undergraduate students. The scale involving 16 articles and 4 sub dimensions and developed by Rothwell, Herbert, and Rothwell (2008) has involved 10 articles and 3 sub dimensions after the adaptation to Turkish society by Karl1 (2016).

After adaptation to Turkish population, the scale involving 4 sub dimensions in original and whose cronbach's alpha internal consistency parameter is .75 has been decreased to $3 \mathrm{sub}$ dimensions and it involves $1 \mathrm{st}, 2 \mathrm{nd}$, 3rd, 
4th articles for "Prestige of University" sub dimension (ES First Dimension), 5th, 6th, 7th articles for "Reliance in Study Area" sub dimension (ES Second Dimension) and 8th, 9th and 10th articles for "Belief in One's Self" sub dimension (BO 3rd Dimension). Cronbach's alpha internal consistency parameter of "Prestige of University" sub dimension which is the first dimension is .79, cronbach's alpha internal consistency parameter of "Reliance in Study Area" sub dimension which is the second sub dimension is .64, and it has been stated that total cronbach's alpha internal consistency parameter of the scale is .81 .

\subsection{Analysis of Data}

In the analysis of data to test hypothesis of the research, besides descriptive statistics such as arithmetic average, standard deviation, frequency/percentage, normal distribution test, (Kolmogorov-Smirnov test), t-test (Mann-Withney U test) and correlation test (Spearman Correlation test) have been used in pairwise comparison and analysis of variance (Kruskal Wallis-H test) has been used in multiple comparisons. SPSS 23 statistical package program has been used to create tables and evaluate the data obtained from the study.

\section{Results and Discussion}

Table 1. Statistical deviations related to demographic features of the participants

\begin{tabular}{llllll}
\hline Gender & $\mathrm{N}$ & $\%$ & Con. Of Taking Ent. Course & $\mathrm{N}$ & $\%$ \\
\hline 1.Female & 230 & 38.5 & 1. Yes & 154 & 25.8 \\
\hline 2. Male & 367 & 61.5 & 2. No & 443 & 74.2 \\
\hline Total & 597 & 100.0 & Total & 597 & 100.0 \\
\hline Graduated H.school & & & Department & \\
\hline 1. Anatolian H.school & 176 & 29.5 & 1. Coaching Education & 146 & 24.5 \\
\hline 2. Science H.school & 58 & 9.7 & 2. Ph.Ed.and Sp. Teaching & 258 & 43.2 \\
\hline 3. Highschool & 158 & 26.5 & 3. Ex. For Disabled People & 32 & 5.4 \\
\hline 4. Vocational H.school & 127 & 21.3 & 4. Recreation & 92 & 15.4 \\
\hline 5. Sport H.school & 78 & 13.1 & 5. Sport Management & 69 & 11.6 \\
\hline Total & 597 & 100.0 & Total & 597 & 100.0 \\
\hline
\end{tabular}

When we examine Table 1, it has been seen that $38.5 \%$ of the participants are female, $61.5 \%$ is male, $25.8 \%$ are the ones that have taken entrepreneurship course and $74.2 \%$ of them are the ones that have not taken entrepreneurship course. It has been stated that $29.5 \%$ of the participants have been graduated from Anatolian Highschool, $9.7 \%$ of them from Science Highschool, $26.5 \%$ of them from highschool, $21.3 \%$ of them from vocational highschool and $13.1 \%$ of them from Sport highschool. It has been pointed out that the deviation according to department variable is $24.5 \%$ with coaching education department, $43.2 \%$ with physical education and sports teaching department, $5.4 \%$ with the department of exercise teaching for disabled people, $15.4 \%$ with recreation department and $11.6 \%$ with sports management department.

Table 2. Comparisons of employability perceptions and entrepreneurship levels of the participants according to gender variable

\begin{tabular}{|c|c|c|c|c|c|c|}
\hline Dependent Variables & Gender & $\mathrm{N}$ & Mean R. & Rank Total & $\mathrm{U}$ & $\mathrm{p}$ \\
\hline \multirow{2}{*}{ Prestige of University } & 1. Female & 230 & 308.48 & 70950.50 & \multirow{2}{*}{40024.500} & \multirow{2}{*}{.286} \\
\hline & 2. Male & 367 & 293.06 & 107552.50 & & \\
\hline \multirow{2}{*}{ Reliance in Study Area } & 1. Female & 230 & 304.62 & 70062.00 & \multirow{2}{*}{40913.000} & \multirow{2}{*}{.526} \\
\hline & 2. Male & 367 & 295.48 & 108441.00 & & \\
\hline \multirow{2}{*}{ Belief in one's self } & 1. Female & 230 & 304.43 & 70018.00 & \multirow{2}{*}{40957.000} & \multirow{2}{*}{.539} \\
\hline & 2. Male & 367 & 295.60 & 108485.00 & & \\
\hline \multirow{2}{*}{ Risk Taking } & 1. Female & 230 & 308.59 & 70976.00 & \multirow{2}{*}{39999.000} & \multirow{2}{*}{.281} \\
\hline & 2. Male & 367 & 292.99 & 107527.00 & & \\
\hline \multirow{2}{*}{ Seeing Opportunities } & 1. Female & 230 & 314.43 & 72319.50 & \multirow{2}{*}{38655.500} & \multirow{2}{*}{.083} \\
\hline & 2. Male & 367 & 289.33 & 106183.50 & & \\
\hline \multirow{2}{*}{ Self Confidence } & 1. Female & 230 & 314.99 & 72448.00 & \multirow{2}{*}{38527.500} & \multirow{2}{*}{.072} \\
\hline & 2. Male & 367 & 288.98 & 106055.00 & & \\
\hline Emotional Intelligence & 1. Female & 230 & 310.29 & 71366.50 & 39608.500 & .205 \\
\hline
\end{tabular}




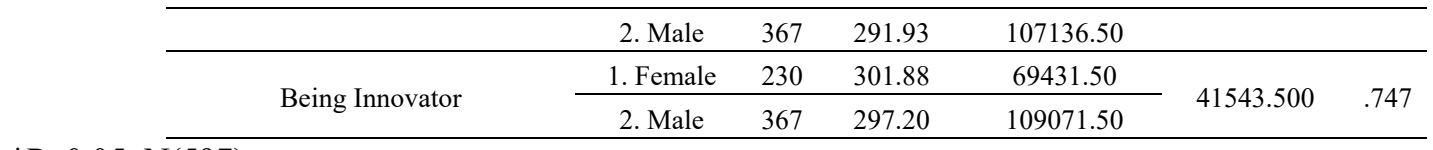

$* \mathrm{P}<0.05 ; \mathrm{N}(597)$.

When we examine Table 2, in the result of Mann-Withney $U$ test conducted to test whether there is a significant difference in employability perceptions and entrepreneurship levels of the participants according to the gender variable, no statistically significant difference has been found in between sub dimensions of gender variable and prestige of university $(\mathrm{U}=40024.500, \mathrm{p}>0.05)$, reliance in study area $(\mathrm{U}=40913.000, \mathrm{p}>0.05)$, belief in one's self $(\mathrm{U}=40957.000, \mathrm{p}>0.05)$, risk taking $(\mathrm{U}=39999.000, \mathrm{p}>0.05)$, seeing opportunities $(\mathrm{U}=38655.500, \mathrm{p}>0.05)$, self-confidence $(U=38527.500, p>0.05)$, emotional intelligence $(U=39608.500, p>0.05)$ and being innovator $(\mathrm{U}=41543.500, \mathrm{p}>0.05)$.

It has not been found out that there is a significant difference in the study to determine the entrepreneurship levels of physical education and sport teacher candidates by Murathan (2019) which is parallel to our study. It has been stated that there is no significant difference in the entrepreneurship points of teacher candidates according to gender in the study by Pan and Akay (2015). It is parallel to our study that there is no significant difference in entrepreneurship levels according to gender variable in the study conducted with the students studying at different departments of Selçuk University by Yllmaz and Sünbül (2009). From this situation, it can be said that gender factor that the students sharing the same university environment acknowledge by comparing pros and cons is not a criteria for this.

Table 3. Comparison of employability perception and entrepreneurship levels according to the condition of taking entrepreneurship course of the participants

\begin{tabular}{|c|c|c|c|c|c|c|}
\hline Dependent Variables & CTEC & $\mathrm{N}$ & Mean R. & Rank Total & $\mathrm{U}$ & $\mathrm{p}$ \\
\hline \multirow{2}{*}{ Prestige of University } & 1. Yes & 154 & 266.52 & 41043.50 & \multirow{2}{*}{29108.500} & \multirow{2}{*}{.006} \\
\hline & 2. No & 443 & 310.29 & 137459.50 & & \\
\hline \multirow{2}{*}{ Reliance in Study Area } & 1. Yes & 154 & 276.56 & 42591.00 & \multirow{2}{*}{30656.000} & \multirow{2}{*}{.059} \\
\hline & 2. No & 443 & 306.80 & 135912.00 & & \\
\hline \multirow{2}{*}{ Belief in one's self } & 1. Yes & 154 & 290.45 & 44730.00 & \multirow{2}{*}{32795.000} & \multirow{2}{*}{.471} \\
\hline & 2. No & 443 & 301.97 & 133773.00 & & \\
\hline \multirow{2}{*}{ Risk Taking } & 1. Yes & 154 & 287.78 & 44318.00 & \multirow{2}{*}{32383.000} & \multirow{2}{*}{.348} \\
\hline & 2. No & 443 & 302.90 & 134185.00 & & \\
\hline \multirow{2}{*}{ Seeing Opportunities } & 1. Yes & 154 & 295.66 & 45531.00 & \multirow{2}{*}{33596.000} & \multirow{2}{*}{.780} \\
\hline & 2. No & 443 & 300.16 & 132972.00 & & \\
\hline \multirow{2}{*}{ Self Confidence } & 1. Yes & 154 & 294.01 & 45277.50 & \multirow{2}{*}{33342.500} & \multirow{2}{*}{.676} \\
\hline & 2. No & 443 & 300.73 & 133225.50 & & \\
\hline \multirow{2}{*}{ Emotional Intelligence } & 1. Yes & 154 & 274.05 & 42203.50 & \multirow{2}{*}{30268.500} & \multirow{2}{*}{.037} \\
\hline & 2. No & 443 & 307.67 & 136299.50 & & \\
\hline \multirow{2}{*}{ Being Innovator } & 1. Yes & 154 & 255.08 & 39283.00 & \multirow{2}{*}{27348.000} & \multirow{2}{*}{.001} \\
\hline & 2. No & 443 & 314.27 & 139220.00 & & \\
\hline
\end{tabular}

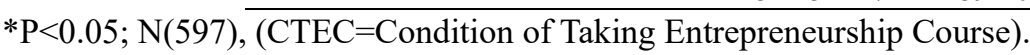

When we examine Table 3, in the result of Mann-Withney $U$ test conducted to test whether there is a significant difference in employability perceptions and entrepreneurship levels of the participants according to the condition of Taking Entrepreneurship Course, when there is statistically significant difference has been found in between sub dimensions of condition of Taking Entrepreneurship Course and prestige of university ( $U=29108.500, p<0.05$ ), emotional intelligence $(\mathrm{U}=30268.500, \mathrm{p}<0.05)$ and being innovator $(\mathrm{U}=27348.000, \mathrm{p}<0.05)$, no statistically significant difference has been found in between sub dimensions of condition of Taking Entrepreneurship Course and reliance in study area $(U=30656.000, p>0.05)$, belief in one's self $(U=32795.000, p>0.05)$, risk taking $(U=32383.000, p>0.05)$, seeing opportunities $(U=33596.000, p>0.05)$ and self-confidence $(U=33342.500, p>0.05$.

From this point, it can be thought that showing significant differences in some sub dimensions of Taking Entrepreneurship Course is because the course fits for purpose. It can be stated that in insignificant sub dimensions 
showing variance in perception levels of the participants and teaching style of the responsible teacher cannot effect on the purpose of the course. It can be seen that in the study by Balaban and Özdemir (2008) which is parallel to our study, when total number of ones who do not take entrepreneurship course use the statements such as they can work with a high salary and high positions, the ones who take entrepreneurship course are more careful about their future. In the scope of condition of taking entrepreneurship course variable when examining mean rank, it can be pointed out that mean ranks of sub dimensions of prestige of university (310.29), emotional intelligence (307.67) and being innovator (314.27) of the participants that do not take entrepreneurship course are higher than mean ranks of sub dimensions of prestige of university (266.52), emotional intelligence (274.05) and being innovator (255.08) of the participants that take entrepreneurship course. It can be said that this situation can be caused from when they take the course, both employability perceptions and entrepreneurship efforts increase and so they see crystal clear the differences and the reality at the point they will reach. Because the ones who do not take the course cannot catch the point of foreseeing the difficulties that they would face after they graduated, it can be stated that they feel like everything is okay and they never face with an obstacle and problem.

Table 4. Variance analysis results of employability perceptions and entrepreneurship levels of the participants according to graduated high school type

\begin{tabular}{|c|c|c|c|c|c|c|c|}
\hline Dependent Variables & GHT & $\mathrm{N}$ & Mean R. & $\mathrm{sd}$ & $\chi^{2}$ & $\mathrm{p}$ & $(\mathrm{I}-\mathrm{J})$ \\
\hline \multirow{5}{*}{ Prestige of University } & 1. Anatolian H.school & 176 & 257.27 & \multirow{5}{*}{4} & \multirow{5}{*}{15.470} & \multirow{5}{*}{.004} & \multirow{5}{*}{$1-3$} \\
\hline & 2. Science H.school & 58 & 331.34 & & & & \\
\hline & 3. Highschool & 158 & 317.97 & & & & \\
\hline & 4. Vocational H.school & 127 & 308.04 & & & & \\
\hline & 5. Sport H.school & 78 & 315.97 & & & & \\
\hline \multirow{5}{*}{ Reliance in Study Area } & 1. Anatolian H.school & 176 & 271.31 & \multirow{5}{*}{4} & \multirow{5}{*}{7.953} & \multirow{5}{*}{.093} & \\
\hline & 2. Science H.school & 58 & 334.74 & & & & \\
\hline & 3. Highschool & 158 & 307.63 & & & & \\
\hline & 4. Vocational H.school & 127 & 303.20 & & & & \\
\hline & 5. Sport H.school & 78 & 310.60 & & & & \\
\hline \multirow{5}{*}{ Belief in one's self } & 1. Anatolian H.school & 176 & 282.17 & \multirow{5}{*}{4} & \multirow{5}{*}{3.722} & \multirow{5}{*}{.445} & \\
\hline & 2. Science H.school & 58 & 285.80 & & & & \\
\hline & 3. Highschool & 158 & 308.39 & & & & \\
\hline & 4. Vocational H.school & 127 & 315.46 & & & & \\
\hline & 5. Sport H.school & 78 & 300.96 & & & & \\
\hline \multirow{5}{*}{ Risk Taking } & 1. Anatolian H.school & 176 & 284.48 & \multirow{5}{*}{4} & \multirow{5}{*}{3.401} & \multirow{5}{*}{.493} & \\
\hline & 2. Science H.school & 58 & 279.22 & & & & \\
\hline & 3. Highschool & 158 & 305.90 & & & & \\
\hline & 4. Vocational H.school & 127 & 312.19 & & & & \\
\hline & 5. Sport H.school & 78 & 311.03 & & & & \\
\hline \multirow{5}{*}{ Seeing Opportunities } & 1. Anatolian H.school & 176 & 299.79 & \multirow{5}{*}{4} & \multirow{5}{*}{2.046} & \multirow{5}{*}{.727} & \\
\hline & 2. Science H.school & 58 & 290.20 & & & & \\
\hline & 3. Highschool & 158 & 286.35 & & & & \\
\hline & 4. Vocational H.school & 127 & 307.39 & & & & \\
\hline & 5. Sport H.school & 78 & 315.72 & & & & \\
\hline \multirow{5}{*}{ Self Confidence } & 1. Anatolian H.school & 176 & 289.40 & \multirow{5}{*}{4} & \multirow{5}{*}{1.571} & \multirow{5}{*}{.814} & \\
\hline & 2. Science H.school & 58 & 297.67 & & & & \\
\hline & 3. Highschool & 158 & 295.39 & & & & \\
\hline & 4. Vocational H.school & 127 & 312.52 & & & & \\
\hline & 5. Sport H.school & 78 & 306.94 & & & & \\
\hline \multirow{5}{*}{ Emotional Intelligence } & 1. Anatolian H.school & 176 & 285.78 & & & & \\
\hline & 2. Science H.school & 58 & 275.43 & & & & \\
\hline & 3. Highschool & 158 & 301.20 & 4 & 4.059 & .398 & \\
\hline & 4. Vocational H.school & 127 & 312.90 & & & & \\
\hline & 5. Sport H.school & 78 & 319.27 & & & & \\
\hline Being Innovator & 1. Anatolian H.school & 176 & 280.83 & 4 & 4188 & $38+2>+2>$ & \\
\hline Demg imliovator & 2. Science H.school & 58 & 286.72 & & 4.100 & .50 & \\
\hline
\end{tabular}




\begin{tabular}{ccc} 
3. Highschool & 158 & 309.23 \\
\hline 4. Vocational H.school & 127 & 316.90 \\
\hline 5. Sport H.school & 78 & 299.26
\end{tabular}

$* \mathrm{P}<0.05 ; * * \mathrm{P}<0.005 ; \mathrm{N}(597),(\mathrm{GHT}=$ Graduated Highschool Type).

When we examine Table 4, in the result of Kruskal Wallis H testconducted to test whether there is a significant difference in employability perceptions and entrepreneurship levels of the participants according to graduated high school type variable, when there is statistically significant difference has been found in between sub dimensions of graduated high school type and prestige of university $\left.\chi^{2}(\mathrm{sd}=4, \mathrm{n}=597)=15.470, \mathrm{p}<0.05\right)$, no statistically significant difference has been found in between sub dimensions of graduated high school type and reliance in study area $\left.\chi^{2}(\mathrm{sd}=4, \mathrm{n}=597)=7.953, \mathrm{p}>0.05\right)$, belief in one's self $\left.\chi^{2}(\mathrm{sd}=4, \mathrm{n}=597)=3.722, \mathrm{p}>0.05\right)$,risk taking $\chi^{2}$ $(\mathrm{sd}=4, \mathrm{n}=597)=3.401, \mathrm{p}>0.05)$, seeing opportunities $\left.\chi^{2}(\mathrm{sd}=4, \mathrm{n}=597)=2.046, \mathrm{p}>0.05\right)$, self-confidence $\chi 2(\mathrm{sd}=4$, $\mathrm{n}=597)=1.571, \mathrm{p}>0.05)$, emotional intelligence $\left.\chi^{2}(\mathrm{sd}=4, \mathrm{n}=597)=4.059, \mathrm{p}>0.05\right)$, and being innovator $\chi^{2}(\mathrm{sd}=4$, $\mathrm{n}=597)=4.188, \mathrm{p}>0.05)$.

In the result of repetitive Mann Whitney $U$ tests conducted to determine the significant difference in sub dimension of prestige of university in between which graduated school type categorizes, it has been reported that when there is statistically significant difference between the participants graduated from Anatolian high school and the ones from regular high school $(\mathrm{U}=6224.000, \mathrm{p}<0.005)$, no statistically significant difference between other graduated high school types $(\mathrm{p}>0.005)$.

It can be said that the significant difference in sub dimension of prestige of university is in only between the participants graduated from Anatolian high school and the ones from regular high school. When examining mean ranks related to the sub dimension of prestige of university, it has been seen that mean ranks (257.27), of the participants graduated from Anatolian high school are lower than the mean ranks of the ones graduated from regular high school (317.97).This situation can be thought that it can caused from the perception of the fact that the ones graduated from Anatolian high school are expected to be always better compared to the ones graduated from regular high schools in terms of their point of view to prestige of universities.

Table 5. Variance analysis results of employability perception and entrepreneurship levels according to department variable

\begin{tabular}{|c|c|c|c|c|c|c|}
\hline Dependent Variables & Department & $\mathrm{N}$ & Mean r. & $\chi^{2}$ & $\mathrm{p}$ & $(\mathrm{I}-\mathrm{J})$ \\
\hline \multirow{5}{*}{ Prestige of University } & 1. Coaching Education & 146 & 323.18 & \multirow{5}{*}{411.826} & \multirow{5}{*}{.019} & \\
\hline & 2. Ph.Ed.and Sp. Teaching & 258 & 284.97 & & & \\
\hline & 3. Ex. For Disabled People & 32 & 351.53 & & & \\
\hline & 4. Recreation & 92 & 266.58 & & & \\
\hline & 5. Sport Management & 69 & 319.18 & & & \\
\hline \multirow{5}{*}{ Reliance in Study Area } & 1. Coaching Education & 146 & 310.12 & \multirow{5}{*}{47.044} & \multirow{5}{*}{.134} & \\
\hline & 2. Ph.Ed.and Sp. Teaching & 258 & 279.16 & & & \\
\hline & 3. Ex. For Disabled People & 32 & 332.73 & & & \\
\hline & 4. Recreation & 92 & 322.24 & & & \\
\hline & 5. Sport Management & 69 & 303.02 & & & \\
\hline \multirow{5}{*}{ Belief in one's self } & 1. Coaching Education & 146 & 312.24 & \multirow{5}{*}{$\begin{array}{r}4 \\
-\end{array} 7.431$} & \multirow{5}{*}{.115} & \\
\hline & 2. Ph.Ed.and Sp. Teaching & 258 & 279.69 & & & \\
\hline & 3. Ex. For Disabled People & 32 & 347.69 & & & \\
\hline & 4. Recreation & 92 & 313.32 & & & \\
\hline & 5. Sport Management & 69 & 301.51 & & & \\
\hline \multirow{5}{*}{ Risk Taking } & 1. Coaching Education & 146 & 318.43 & \multirow{5}{*}{$4 \quad 10.547$} & \multirow{5}{*}{.032} & \\
\hline & 2. Ph.Ed.and Sp. Teaching & 258 & 281.71 & & & \\
\hline & 3. Ex. For Disabled People & 32 & 317.61 & & & \\
\hline & 4. Recreation & 92 & 332.90 & & & \\
\hline & 5. Sport Management & 69 & 268.71 & & & \\
\hline \multirow{3}{*}{ Seeing Opportunities } & 1. Coaching Education & 146 & 281.39 & \multirow{3}{*}{411.560} & \multirow{3}{*}{.021} & \multirow{3}{*}{$1-4$} \\
\hline & 2. Ph.Ed.and Sp. Teaching & 258 & 292.16 & & & \\
\hline & 3. Ex. For Disabled People & 32 & 337.58 & & & \\
\hline
\end{tabular}




\begin{tabular}{|c|c|c|c|c|c|c|}
\hline & 4. Recreation & 92 & 347.05 & & & \\
\hline & 5. Sport Management & 69 & 279.85 & & & \\
\hline \multirow{5}{*}{ Self Confidence } & 1. Coaching Education & 146 & 277.01 & \multirow{5}{*}{14.838} & \multirow{5}{*}{3.005} & \multirow{5}{*}{$1-4,4-5$} \\
\hline & 2. Ph.Ed.and Sp. Teaching & 258 & 299.61 & & & \\
\hline & 3. Ex. For Disabled People & 32 & 330.77 & & & \\
\hline & 4. Recreation & 92 & 349.68 & & & \\
\hline & 5. Sport Management & 69 & 260.93 & & & \\
\hline \multirow{5}{*}{ Emotional Intelligence } & 1. Coaching Education & 146 & 300.64 & \multirow{5}{*}{4.079} & \multirow{5}{*}{.395} & \\
\hline & 2. Ph.Ed.and Sp. Teaching & 258 & 290.78 & & & \\
\hline & 3. Ex. For Disabled People & 32 & 345.09 & & & \\
\hline & 4. Recreation & 92 & 314.13 & & & \\
\hline & 5. Sport Management & 69 & 284.72 & & & \\
\hline \multirow{5}{*}{ Being Innovator } & 1. Coaching Education & 146 & 297.67 & \multirow{5}{*}{4.911} & \multirow{5}{*}{.297} & \\
\hline & 2. Ph.Ed.and Sp. Teaching & 258 & 304.53 & & & \\
\hline & 3. Ex. For Disabled People & 32 & 349.73 & & & \\
\hline & 4. Recreation & 92 & 276.80 & & & \\
\hline & 5. Sport Management & 69 & 287.20 & & & \\
\hline
\end{tabular}

$* \mathrm{P}<0.05 ; * * \mathrm{P}<0.005 ; \mathrm{N}(597)$.

When we examine Table 5, in the result of Kruskal Wallis $\mathrm{H}$ testconducted to test whether there is a significant difference in employability perceptions and entrepreneurship levels of the participants according to department variable, when there is statistically significant difference between sub dimension of department variable and prestige of university $\left.\chi^{2}(\mathrm{sd}=4, \mathrm{n}=597)=11.826, \mathrm{p}<0.05\right)$, risk taking $\left.\chi^{2}(\mathrm{sd}=4, \mathrm{n}=597)=10.547, \mathrm{p}<0.05\right)$, seeing opportunities $\left.\chi^{2}(\mathrm{sd}=4, \mathrm{n}=597)=11.560, \mathrm{p}<0.05\right)$ and self-confidence $\left.\chi^{2}(\mathrm{sd}=4, \mathrm{n}=597)=14.838, \mathrm{p}<0.05\right)$, no statistically difference has been found between sub dimensions of department variable and reliance in study area $\chi 2$ $(\mathrm{sd}=4, \mathrm{n}=597)=7.044, \mathrm{p}>0.05)$, belief in one's self $\left.\chi^{2}(\mathrm{sd}=4, \mathrm{n}=597)=7.431, \mathrm{p}>0.05\right)$, emotional intelligence $\chi^{2}$ $(\mathrm{sd}=4, \mathrm{n}=597)=4.079, \mathrm{p}>0.05)$ and being innovator $\left.\chi^{2}(\mathrm{sd}=4, \mathrm{n}=597)=4.911, \mathrm{p}>0.05\right)$.

In the scope of department variable, in the result of repetitive Mann Whitney $U$ tests conducted to determine the significant difference in sub dimension in between which departments of in sub dimensions of prestige of university, risk taking, seeing opportunities and self-confidence, while it has been found out that there are statistically significant differences in seeing opportunities sub dimension between the participants studying coaching education and the ones studying recreation $(\mathrm{U}=5269.000, \mathrm{p}<0.005)$, in self-confidence sub dimension between the participants studying recreation department and the ones coaching education $(U=5079.000, p<0.005)$ and the ones studying sports management department $(U=2240.000, p<0.005)$, there has been no statistically significant difference between other departments ( $p>0.005)$. Although it has been identified that there is significant difference in sub dimensions of prestige of university and risk taking in the result of Kruskal Wallis $\mathrm{H}$ test conducted according to department variable, because the values related to significant levels obtained from Mann Whitney $U$ tests in risk taking and prestige of university sub dimensions with the aim of prevent type I and type II mistakes to be caused from repetitive Mann Whitney $U$ test are higher than new defined significant level $(p>0.005)$ it has been interpreted as there is no significant difference.

It has been seen that there is a significant difference between the participant studying coaching education department and the ones studying recreation in sub dimension of seeing opportunities in the scope of department. According to the seeing opportunities sub dimension mean rank, it has been recorded that the mean rank of the participants studying recreation department (347.05) is higher than the mean rank of the participants studying recreation department (281.39). In the study by Gümüşsay (2014) it has been pointed out that employability perceptions of the students studying recreation are higher than the students of other departments. With this point, parallel to our study it can be thought that the participants of recreation department are one step forward in terms of seeing the opportunities when considering recreation departments' not taking its rightful place in government assignments yet, constraint in the rates of assignments and seasonal working facilities caused by the fact that working places are not touristic places. In the scope of department variable, in self-confidence sub dimension, it has been stated that there is statistically significant difference between the participants studying recreation and the ones studying coaching education and sports management. When looking into the mean rank of self-confidence sub dimension, it has been seen that the mean rank of the participants studying recreation (349.68) are higher than the mean rank of the participants studying coaching education (277.01) and sports management (260.93). Likewise 
in seeing opportunities sub dimension, this situation can be thought that not only they can each moment which they are living into opportunity in positive extent but also they increase their self-confidence by catching these advantages.

Table 6. Correlation test results between employability perception and entrepreneurship levels of the participants

\begin{tabular}{cccccccc}
\hline & ÜP & ÇAG & KOİ & RA & FG & KG & DZ \\
\hline ÇAG & $.437^{* *}$ & & & & & & \\
\hline KOİ & $.346^{* *}$ & $.424^{* *}$ & & & & & \\
\hline RA & $.363^{* *}$ & $.375^{* *}$ & $.389^{* *}$ & & & & \\
\hline FG & $.232^{* *}$ & $.272^{* *}$ & $.345^{* *}$ & $.556^{* *}$ & & & \\
\hline KG & $.217^{* *}$ & $.248^{* *}$ & $.331^{* *}$ & $.567^{* *}$ & $.626^{* *}$ & & \\
\hline DZ & $.287^{* *}$ & $.280^{* *}$ & $.311^{* *}$ & $.550^{* *}$ & $.571^{* *}$ & $.496^{* *}$ & \\
\hline YO & $.343^{* *}$ & $.382^{* *}$ & $.257^{* *}$ & $.431^{* *}$ & $.475^{* *}$ & $.435^{* *}$ & $.551^{* *}$ \\
\hline
\end{tabular}

$* * \mathrm{P}<0.01 ; \mathrm{N}(597)$.

When we examine Table 6 , in the result of spearman correlation testconducted to test whether there is a significant relation between employability perceptions and entrepreneurship levels of the participants, when it has been identified that there is statistically significant relation in moderately positive way between prestige of university sub dimension and reliance in study areas $(\mathrm{r}=.437 ; \mathrm{p}<0.01)$, belief in one's self $(\mathrm{r}=.346 ; \mathrm{p}<0.01)$, risk taking $(\mathrm{r}=.363 ; \mathrm{p}<0.01)$, and being innovator $(\mathrm{r}=.343 ; \mathrm{p}<0.01)$ sub dimensions, it has been pointed out that there is significant relation in low positive way between reliance in study area sub dimension and seeing opportunities $(\mathrm{r}=.272 ; \mathrm{p}<0.01)$, self-confidence $(\mathrm{r}=.248 ; \mathrm{p}<0.01)$ andemotional intelligence $(\mathrm{r}=.280 ; \mathrm{p}<0.01)$. when it has been stated that there is statistically significant relation in positively lower way between belief in one's self sub dimension and being innovator $(\mathrm{r}=.257 ; \mathrm{p}<0.01)$, it has been reported that there is statistically significant relation in moderately positive way between belief in one's self sub dimension and risk taking $(r=.389 ; \mathrm{p}<0.01)$, seeing opportunities $(r=.345 ; \mathrm{p}<0.01)$, self-confidence $(\mathrm{r}=.331 ; \mathrm{p}<0.01)$ and emotional intelligence $(\mathrm{r}=.311 ; \mathrm{p}<0.01)$.

It has been determined that there is statistically significant relation in moderately positive way between risk taking sub dimension and seeing opportunities $(\mathrm{r}=.556 ; \mathrm{p}<0.01)$, self-confidence $(\mathrm{r}=.567 ; \mathrm{p}<0.01)$, emotional intelligence $(\mathrm{r}=.550 ; \mathrm{p}<0.01)$ and being innovator $(\mathrm{r}=.431 ; \mathrm{p}<0.01)$ sub dimensions. It has been found out that there is statistically significant relation in moderately positive way between seeing opportunities sub dimension and self-confidence $(r=.626 ; p<0.01)$, emotional intelligence $(r=.571 ; p<0.01)$ and being innovator $(r=.475 ; p<0.01)$ sub dimensions and emotional intelligence sub dimension and being innovator $(\mathrm{r}=.551 ; \mathrm{p}<0.01)$ sub dimension.

It has been seen that there is positively significant at the lowest level between prestige of university and self -confidence sub dimension $(r=0,217, \mathrm{p}<0.01)$. When we look into the determination parameter $(\mathrm{r} 2=0.07)$, it can be stated that 5 percentage of the difference in self confidence level of the participants can be caused from the fact that the perception of prestige of university is strong. In other words, we can say that as prestige of university perception level of the participants increases, their self-confidence shows an increase too.

It has been seen that there is positively significant at the highest level between seeing opportunities sub dimension and self-confidence sub dimension $(\mathrm{r}=0,626, \mathrm{p}<0.01)$. When we look into the determination parameter $(\mathrm{r} 2=0.39)$, it can be said that 39 percentage of the difference in self confidence level of the participants can be caused from seeing opportunities variable. In other words, we can say that many facilities in labor market also effect participants' self confidence in a positive way.

\section{Conclusion}

As a consequence, it has been found out that there is a significant difference in Employability Scale and Entrepreneurship Scale for Teacher Candidates sub dimensions according to Condition of Taking Entrepreneurship Course, High school Type and Department Variables in the investigation of Ent5repreneurship levels and Employability perceptions of the undergraduate students in Sports Science. According to gender variable, there is no significant difference. At the same time, it has been found out that there is a significant difference in employability perceptions and entrepreneurship levels of the undergraduate students. In next studies it has been thought that there could be different results by comparing the students in Sport Science from different regions and cities of population and sample groups, students from different departments or undergraduate students and students from higher education. 


\section{References}

Arthur, M. B., \& Rousseau, D. M. (1996). Introduction: The boundaryless career as a new employment principle. The boundaryless career: A new employment principle for a new organizational era (pp. 3-20).

Balaban, Ö., \& Özdemir, Y. (2008). Girişimcilik Eğitiminin Girişimcilik Eğilimi Üzerindeki Etkisi: Sakarya üniversitesi IIIBF örneği.

Deveci, İ., \& Çepni, S. (2015). Öğretmen Adaylarına Yönelik Girişimcilik Ölçeğinin Geliştirilmesi: Geçerlik ve Güvenirlik Çalışması. International Journal of Human Sciences, 12(2), 92-112. https://doi.org/10.14687/ijhs.v12i2.3240

Eroğlu, S. Y., \& Acet, M. (2017). İşitme Engelli Öğrencilerin Spor Yapma Değişkenine Göre Sosyal Görünüş Kaygısı ile Yaşam Kalitesi Düzeylerinin İncelenmesi. Türkiye Klinikleri Spor Bilimleri, 9(2).

Forrier, A., \& Sels, L. (2003). The Concept of Employability: A Complex Mosaic. International Journal of Human Resources Development and Management, 3(2), 102-124. https://doi.org/10.1504/IJHRDM.2003.002414

Gümüşay, A. (2014). Beden Ĕgitimi ve Spor Yüksekokulu Öğrencilerinin İstihdam Edilebilme Algısl. Yüksek Lisans Tezi, Niğde Üniversitesi/Sosyal Bilimler Enstitüsü.

Havinal, V. (2009). Management and Entrepreneurship. New Delhi: New Age International.

Hillage, J., \& Pollard, E. (1998). Employability: Developing a Framework for Policy Analysis. London: DfEE.

Hisrich, R. D., \& Peters, M. P. (2002). Entrepreneurship (5th ed.). McGraw Hill Irwin.

Karli, U. (2016). Adaptation and Validation of Self-Perceived Employability Scale. An Analysis of Sports Department Students and Graduates. Educational Research and Reviews, 11(8), 848-859.

Kaya, A. (2007). Bilişsim ve İletişsim Işı̆̆ı̆nda Girişimcilik ve Kobi Yönetimi. Konya: Eğitim Kitabevi Yayınları.

Kocacık, F. (2000). Çalışma Sosyolojisi. Sivas: Dilek Ofset Matbaacılık.

Kuratko, D. F. (2009). Introduction to Entrepreneurship (9th ed.). South-Western: Cengage Learning.

Murathan T. (2019). Beden Eğitimi Öğretmen Adaylarının Girişimcilik Düzeylerinin Belirlenmesi. Social Mentality and Researcher Thinkers Journal, 5(24). 1518-1526. https://doi.org/10.31576/smryj.364

Pan, V., \& Akay, C. (2015). EĞITIMM FAKÜLTESİ ÖĞRENCILERININ GIRIŞIMCILIK DÜZEYLERININ ÇEŞiTLİ DEĞİŞKENLER AÇISINDAN İNCELENMESİ. Education Sciences, 10(2), 125-138. https://doi.org/10.12739/NWSA.2015.10.2.1C0637

Rothwell, A., Herbert, I., \& Rothwell, F. (2008). Self-Perceived Employability: Construction and İnitial Validation of A Scale For University Students. Journal of Vocational Behavior, 73(1), 1-12. https://doi.org/10.1016/j.jvb.2007.12.001

Saygıl1, Ş. K., Cihan, C., \& Yurtoğlu, H. (2002). Türkiye Ekonomisinde Sermaye Birikimi, Büyüme ve Verimlilik 1972-2000. Ankara: DPT Ekonomik Modeller ve Stratejik Araştırmalar Genel Müdürlüğü.

Yilmaz, E., \& Sünbül, A., M. (2009). Üniversite Öğrencilerine Yönelik Girişimcilik Ölçeğinin Geliştirilmesi. Selçuk Üniversitesi Sosyal Bilimler Enstitüsü Dergisi, 21, 195-203.

\section{Copyrights}

Copyright for this article is retained by the author(s), with first publication rights granted to the journal.

This is an open-access article distributed under the terms and conditions of the Creative Commons Attribution license (http://creativecommons.org/licenses/by/4.0/). 